\title{
Asthma diagnosis and treatment - 1024. Prevalence of depression among asthma patients and effects of asthma control on severity of depression
}

\author{
Poonam Kumar ${ }^{1 *}$, Swapnendu Misra², Susmita Kundu ${ }^{3}$, AG Ghoshal ${ }^{4}$, Debabrata Majumdar ${ }^{5}$ \\ From 2nd WAO International Scientific Conference (WISC 2012) \\ Hyderabad, India. 6-9 December 2012
}

\section{Background}

Asthma is a serious global health problem. Global prevalence of asthma ranges from $1 \%$ to $18 \%$ of population in different countries.

In India, prevalence of asthma is $3 \%$ of the population. Major depressive disorder is the most common mood disorder often found to be higher among people with chronic health conditions like asthma. Presence of depression may lead to increased severity of asthma making it an uncontrolled asthma.

Our objective was to see prevalence of depression among asthma patients and effect of asthma control on severity of depression.

\section{Methods}

All patients who met the inclusion criteria evaluated with Goldberg's The General Health Questionnaire (GHQ 28), Bengali Version of Beck Depression Inventory (BDI) and Holmes \& Rahe's Life Event Scale. Severity of asthma and level of asthma control determined as per GINA guidelines. Follow up was done after 3 months and patients were again evaluated with Goldberg's The General Health Questionnaire (GHQ 28), Bengali Version of Beck Depression Inventory (BDI) and Holmes \& Rahe's Life Event Scale.

\section{Results}

Among 100 patients 35 (35\%) had normal BDI score, mild mood disturbance was found in 23 (23\%), borderline clinical depression in 12 (12\%), moderate depression in
$20(20 \%)$, severe depression in $9(9 \%)$, extreme depression in $1(1 \%)$ patients. Follow up done at 3 months showed 68 patients had controlled and 32 patients had partially controlled asthma. Follow up evaluation with BDI showed 37 (37\%) patients had normal score. Mild mood disturbance was found in 24 (24\%), borderline clinical depression in $16(16 \%)$, moderate depression in $14(14 \%)$, severe depression in $8(8 \%)$, extreme depression in $1(1 \%)$ patients.

There is no significant correlation between severity of asthma and severity of depression (Correlation coefficient 0.047 , $\mathrm{p}$ value 0.322 ).

There is also no correlation of asthma control on severity of depression (Correlation coefficient -0.036 , p value 0.362 ).

\section{Conclusions}

Depression is highly prevalent among asthma patients. There is no significant correlation between severity of asthma and severity of depression. There is also no correlation of asthma control on severity of depression.

\section{Author details \\ ${ }^{1}$ Respiratory Diseases and Clinical Immunology Society, India. ${ }^{2}$ Pulmonary Medicine, Kolkata, India. ${ }^{3}$ Pulmonary Medicine, R G Kar Medical College, Kolkata, India. ${ }^{4}$ National Allergy Asthma Bronchitis Institute,Kolkata, India. ${ }^{5}$ sychiatry, Kolkata, India.}

Published: 23 April 2013

${ }^{1}$ Respiratory Diseases and Clinical Immunology Society, India

Full list of author information is available at the end of the article

(c) 2013 Kumar et al; licensee BioMed Central Ltd. This is an Open Access article distributed under the terms of the Creative Commons 
doi:10.1186/1939-4551-6-S1-P23

Cite this article as: Kumar et al:: Asthma diagnosis and treatment -

1024. Prevalence of depression among asthma patients and effects of

asthma control on severity of depression. World Allergy Organization

Journal 2013 6(Suppl 1):P23.

Submit your next manuscript to BioMed Central and take full advantage of:

- Convenient online submission

- Thorough peer review

- No space constraints or color figure charges

- Immediate publication on acceptance

- Inclusion in PubMed, CAS, Scopus and Google Scholar

- Research which is freely available for redistribution

Submit your manuscript at 